Licença CC BY: Artigo distribuído sob os termos Creative Commons, permite uso e distribuição irrestrita em qualquer meio desde que o autor credite a fonte original.

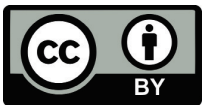

\title{
TURISMO E PAISAGENS LACUSTRES: UMA ANÁLISE ESTÉTICA DE FOTOGRAFIAS DA LAGOA MIRIM (BRASIL/URUGUAI)
}

\author{
TOURISM AND LAKE LANDSCAPES: AN AESTHETIC ANALYSIS OF \\ PHOTOGRAPHS OF LAGOA MIRIM (BRAZIL/URUGUAY)
}
TURISMO Y PAISAJES LACUSTRES: UN ANÁLISIS ESTÉTICO DE FOTOGRAFÍAS DE LAGOA MIRIM (BRASIL/URUGUAY)

\author{
JACIEL GUSTAVO KUNZ'
}

\section{ANTONIO CARLOS CASTROGIOVANNI²}
IUNIVERSIDADE FEDERAL DO RIO GRANDE, SANTA VITÓRIA DO PALMAR, RIO GRANDE DO SUL, BRASIL.

${ }^{2}$ UNIVERSIDADE FEDERAL DO RIO GRANDE DO SUL, PORTO ALEGRE, RIO GRANDE DO SUL, BRASIL.

\begin{abstract}
DATA DE SUBMISSÃO: 14/08/2019 - DATA DE ACEITE: 12/10/2019
RESUMO: A experiência turística da paisagem é marcadamente estética. A fotografia dos turistas é, também, prática geográfica. O objetivo desse artigo é analisar como funcionam esteticamente fotografias de paisagens da Lagoa Mirim (Brasil/Uruguai), clicadas de 2000 a 2018, e disponibilizadas no repositório Flickr ${ }^{\circledR}$. Como objetivos específicos, descrevemos os documentos em análise e caracterizamos os sítios estudados: Praia/Vila da Capilha e Porto de Santa Vitória, no Brasil; e Balneário de Lago Merín, no Uruguai. Na interface entre Turismo e Geografia, estabelecemos um estado do conhecimento dos temas em questão. Analisamos o conteúdo de 65 fotografias e das legendas disponíveis. Do estudo da Lagoa Mirim como objeto geográfico, identificamos como principais conotações estéticas de sua paisagem turística: a dominância romântica do pitoresco e do melancólico; a relevância do pôr do sol no "lado" brasileiro; uma vacationscape de balneário em Lago Merín; e a recorrência de temas de aventura na Capilha. Encontramos, ainda, algumas ambiguidades entre 0 pitoresco e o sublime. Nosso intuito é oferecer ferramental teórico-metodológica para estudo de paisagens turísticas por meio de fotografias.
\end{abstract}

PALAVRAS-CHAVE: Turismo; Paisagens; Estética; Fotografia; Lagoa Mirim.

Jaciel Professor da Universidade Federal do Rio Grande, Santa Vitória do Palmar, Rio Grande do Sul, Brasil. Doutorando em Geografia pela Universidade Federal do Rio Grande do Sul, Porto Alegre, Rio Grande do Sul, Brasil. E-mail: jacielkunz@gmail.com. Orcid: https://orcid.org/0000-0002-0578-2457

Antonio Carlos Professor da Pontifícia Universidade Católica do Rio Grande do Sul, Porto Alegre, Rio Grande do Sul, Brasil. Doutor em comunicação social pela Pontifícia Universidade Católica do Rio Grande do Sul, Porto Alegre, Rio Grande do Sul, Brasil. E-mail: castroge@ig.com.br. Orcid: https://orcid.org/0000-0002-2146-9700 


\begin{abstract}
Tourist experiences of landscape are highly aesthetic. Moreover, tourist photography is a geographical practice. The goal of this work is to analyze how tourists' photographs of landscapes of Lagoa Mirim, a lake located on the Brazil-Uruguay border, function in terms of aesthetics. The photographs were taken between 2000 and 2018 , and are available in the Flickr ${ }^{\circledR}$ repository. The specific goals of this work were to describe the documents under analysis, and to characterize the studied sites: Praia/Vila de Capilha and Porto de Santa Vitória, both in Brazil, and Balneário de Lago Merín, in Uruguay. In the interface between Tourism and Geography, we established the state-of-art in terms of research on the themes debated. We also analyzed, iconically, the content of 65 photographs and the available captions. From the study of Lagoa Mirim as a geographic object, we identified key aesthetic connotations of its touristscape: a predominance of picturesque and melancholic-romantic; the relevance of the sunset on the Brazilian side of the lake; a vacationscape of the seashore in Lago Merín; and the prevalence of adventure motifs in Capilha. We also found some ambiguities between picturesque and sublime. Our aim is to provide a theoretical and methodological framework for the study of touristscapes through photography.
\end{abstract}

KEYWORDS: Tourism; Landscapes; Aesthetics; Photography; Lagoa Mirim

RESUMEN: La experiencia turística del paisaje es notablemente estética. La fotografía turística es también práctica geográfica. En este artículo, el objetivo es analizar estéticamente las fotografías de paisajes de la Laguna Merín (Brasil / Uruguay), sacadas entre 2000 y 2018, y disponibles en el repositorio Flickr. Como objetivos específicos, describimos los documentos bajo análisis y los puntos estudiados: Playa/Villa de la Capilla y Puerto de Santa Victória, en Brasil, y Lago Merín, en Uruguay. En la interfaz entre Turismo y Geografía, establecimos un estado del arte de los temas en cuestión. Hemos revisado el contenido de 65 fotografías y los subtítulos disponibles. Del estudio de la Laguna Merín como objeto geográfico, identificamos las principales connotaciones estéticas de su paisaje turístico: el dominio del romántico del pintoresco y melancólico; la relevancia de la puesta del sol no en el "lado" brasileño; un paisaje vacationscape en Lago Merín; y la recurrencia de temas de aventura en La Capilla. Hay también algunas ambigüedades entre lo pintoresco y lo sublime. Nuestro objetivo es proporcionar herramientas teóricas y metodológicas para estudiar el paisaje turístico a través de fotografías.

PALABRAS CLAVE: Turismo; Paisajes; Estética; Fotografía; Laguna Merín.

\title{
1. OBJETIVOS, INQUIETAÇÕES E OBJETO EMPÍRICO
}

A paisagem é relevante à experiência turística. Os turistas não experenciam um destino como uma série de objetos separados, mas uma paisagem inteira (Knudsen, Rickly-Boyd \& Metro-Roland, 2012). Certas paisagens têm atrativos para os turistas, pois acionam certas imagens mentais: a imaginação é um componente essencial. Vacationscapes (paisagem de férias) são produzidas por meio da interação entre elementos da paisagem, das mentalidades e das tecnologias de mobilidade/ representação (Löfgren, 1999).

Concebemos o turismo como parte importante na maneira pela qual percebemos e sentimos o mundo, onde quer que estejamos, o que quer que façamos. O turismo porta seu próprio kit de técnicas, tecnologias, predisposições e sensibilidades estéticas (Franklin \& Crang, 2001). Há destacado papel da estética na experiência 
turística (Knudsen, Metro-Roland \& Rickly-Boyd, 2015). Em realidade, toda percepção e experiência possuem caráter estético: "[...] visão da paisagem suscita a experiência estética." (Andriolo, 2016: 95). No turismo, os encontros dos sujeitos com as paisagens por vezes têm caráter geográfico-estético e, menos frequentemente, uma dimensão cognitivo-funcional (Pimentel, 2010). Potocka (2013), ao falar sobre paisagens lacustres, frisa que os valores visuais/estéticos da paisagem determinam, pelo menos em parte, as práticas de turismo/lazer no ambiente natural.

A resposta emocional aos ambientes e às paisagens é paralela à resposta estética (Tuan, 2012). Uma paisagem avaliada socialmente de modo positivo pode ou não ser uma paisagem com grande potencial estético (Brook, 2014). O olhar turístico institucionaliza algumas vistas ou alguns comportamentos, enquanto deslegitima (ou simplesmente não legitima) outros (Pimentel, 2010). Na sua relação com a paisagem, o turismo é reconhecido como prática de atribuição de significados, por meio da interação ativa com os objetos (Soica, 2016). Logo, é recomendável que os insights trazidos pelos estudos das paisagens nos ajudem a entender como os sítios e os destinos turísticos são escolhidos (Knudsen, Rickly-Boyd \& Metro-Roland, 2012). Ainda, notamos o papel da estética e da fotografia em garantir visibilidade a determinadas paisagens no/ do turismo. "Fotografar é atribuir importância." (Sontag, 2004: 41).

A história social e cultural do turismo demonstra que novas sensibilidades redundam em novos modos de perceber a paisagem (Löfgren, 1999). A excitação característica deste tempo de alta mobilidade e de turismo gera novas relações sociais, novos modos de vida, novos vínculos com o espaço e novas formas de lazer (Franklin \& Crang, 2001). Mas, embora as tecnologias de dramatização das imagens mudem substancialmente (assim como ocorre com performances turísticas), a sensibilidade estética que condiciona o modo de olhar altera-se pouco: há certo conservadorismo, que retoma o Romântico, linguagem literária e pictórico-visual, que propunha uma fuga ao passado (Gastal, 2013). As pinturas de paisagens em cidades turísticas, apesar de apresentarem novas significações, atestam a manutenção de um "[...] núcleo imagético tradicional." (Andriolo, 2016: 98). Em que pese sua relevância para a experiência turística, a estética segue pouco estudada (Knudsen, Metro-Roland \& Rickly-Boyd, 2015). Isso vale para a Geografia e para o Turismo.

O conjunto da paisagem turística forma um dos três principais construtos/eixos para avaliação da imagem de destinos, a qual transita entre a projeção do marketing e a percepção dos turistas (Hunter, 2016). A revisão dos estudos sobre imagem de destinos realizada recentemente por Picazo e Moreno-Gil (2019), embora cite as paisagens e as fotografias, não aponta a inclusão das categorias estéticas subjacentes a elas. Os referidos autores citam, como agenda para esse tipo de estudo, a aplicação em outros continentes e regiões, como a América Latina, bem como a realização de comparativos entre destinos, e a partir de plataformas como o Flickr (Picazo \& Moreno-Gil, 2019).

Apesar de o turismo constituir-se em fenômeno marcadamente visual, permanece uma relativa falta de uso das metodologias visuais na pesquisa na área, embora com crescente adoção no período recente (Scarles, 2014). O estudo da imagema está sendo negligenciado no Turismo (Gastal, 2013). A técnica fotográfica permite descrever a

a Não estamos nesse trecho nos referindo aos conceitos de imagem de destinos turísticos, embora haja relação. 
significância dos locais e das paisagens, bem como suas experiências, experiências e encontros (Bell, 2010). Diante disso, o resgate desse assunto na Geografia, por meio do conceito de paisagem, nos acena como possibilidade de superação.

Ainda, as plataformas da internet contribuem para $\circ$ registro e para $\circ$ compartilhamento instantâneo das experiências turísticas das atrações e dos destinos, e não só como meio de informações sobre esses (Munar \& Jacobsen, 2014). Em uma era de expansão da mídia visual em novos formatos portáveis, e com a emergência do compartilhamento de fotografias, é indesejável rejeitar os métodos visuais (Crang, 2009).

Diante desses elementos, o objetivo desta pesquisa foi analisar como atuam as categorias estéticas presentes em fotografias digitais das paisagens da Lagoa Mirim (Brasil/Uruguai) e disponibilizadas no repositório Flickr ${ }^{\oplus}$. Como objetivos específicos, caracterizamos a área de estudo em termos gerais e quanto às intencionalidades do turismo/lazer; descrevemos o material documental encontrado, de acordo com suas características básicas; e comparamos os resultados conforme os três sítios estudados: 1) Praia da Capilha (Rio Grande) e 2) Porto Pindorama (Santa Vitória do Palmar), no "lado" brasileiro, e 3) Balneário de Lago Merín (departamento de Cerro Largo), no "lado" uruguaio. A Figura 1 refere-se ao mapa de localização da área de estudo - fotos dos locais são mostradas na quarta seção.

Figura 1 - Mapa de localização da área em estudo
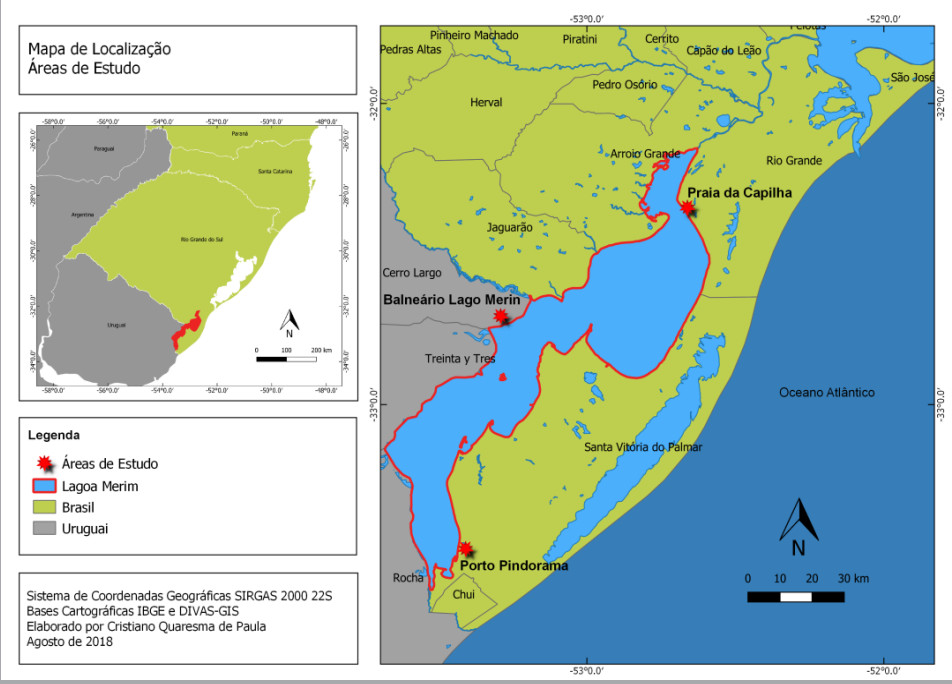

Fonte: Cristiano Quaresma de Paula (2018).

A Mirim está localizada em uma enorme planície costeira, na área mais meridional do Brasil, e é separada do Oceano Atlântico por uma extensa e estreita faixa de terrenos baixos, unindo-se à Laguna dos Patos pelo Canal de São Gonçalo, que, em Rio Grande, deságua no Oceano Atlântico (Schäfer et al., 2009). O talvegue ${ }^{b}$ da Lagoa serve como limite entre o Brasil e o Uruguai em determinadas porções, segundo Tratado de 1909.

Dois terços da superfície da Lagoa correspondem ao Brasil e um terço ao Uruguai, prevalecendo o regime de águas compartilhadas, de acordo com tratados b Linha de maior profundidade na Lagoa. 
da década de $1970^{\circ}$. A palavra "mirim" remete à pequenez ou à infância, mesmo que a Lagoa em estudo seja o segundo maior lago do Brasil, atrás apenas da Laguna dos Patos, e é a maior do Uruguai. Quando comparada à Laguna dos Patos, próxima dali, é que a Lagoa Mirim recebe esse nome. A Mirim ocupa superfície de $3.749 \mathrm{~km}^{2}$, possuindo $185 \mathrm{~km}$ de extensão e largura de 20km, em média (ALM, 2019). Eventos de regressão/ transgressão marinhas dos últimos seis mil anos foram decisivos para a conformação das lagoas nessa seção da Planície Costeira (Schäfer, 2009). Em termos ecológicos, mencionamos a Estação Ecológica do Taim ${ }^{d}$ - ESEC Taim, importante e restritiva unidade de conservação, com diversificada fauna e flora, próximo à Capilha (ALM, 2017).

O "lado" brasileiro, nas margens ocidental e oriental, é conhecido como corredor turístico entre Porto Alegre e os destinos do Uruguai (notadamente Montevidéu e Punta del Este), com ocasionais paradas para compras nas lojas e/ou free shops do Chuí/Chuye ou de Jaguarão/Río Branco. Apesar das belezas cênicas da Lagoa e do Oceano, bem como das numerosas possibilidades do turismo náutico, a infraestrutura e a demanda turísticas são ainda escassas, por razões diversas. Por questões de viabilidade e de realização metodológica, optamos por três recortes espaciais, que são alguns dos principais sítios ${ }^{f}$ de encontro dos turistas com as paisagens da Lagoa Mirim. Assim, é possível um estudo multissituado, contemplando os dois "lados" da fronteira, em uma diversidade de situações e processos. Vemos os três sítios escolhidos como versões turísticas de uma mesma paisagem lacustre, ou de um mesmo objeto geográfico, "Lagoa", que é binacional.

A Vila da Capilha, ou Vila-sede do distrito do Taim (a $400 \mathrm{~km}$ de Porto Alegre), é o ponto mais próximo da Lagoa com a BR-471 - único acesso do Chuí ao restante do país. Fica à beira da Praia da Capilha, com falésias. O nome (capela, espanhol) referese a uma pequena capela construída no tempo do Império. A Capilha é uma vila de pescadores artesanais, em meio a uma região onde a orizicultura e a agropecuária são atividades-chave. Esse sítio vem ascendendo como sítio de férias ou excursões, sobretudo na curta temporada de verão, apesar da infraestrutura de hospedagem e alimentação ainda escassas.

O Porto Pindorama, ou Porto de Santa Vitória do Palmar (cidade a $500 \mathrm{~km}$ de Porto Alegre), funcionou entre 1940 a 1970. No começo do século passado, a navegação na Lagoa era intensa, até que, com a construção da rodovia, o transporte lacustre de cargas e passageiros foi desativado. Junto ao terminal inutilizado para tal, há um espaço de lazer e um museu paleontológico. Próximo a uma comunidade de pescadores, o Porto é visitado pela população local, e ocasionalmente por visitantes que cruzam a região. Ao analisar a qualidade visual do Porto para fins de ecoturismo, a paisagem possui diversidade média, naturalidade média-superior, grande singularidade, detratores pequenos e grandes, e qualidade visual média-superior (Varnier, 2017).

c Tratado de Cooperação para o Aproveitamento dos Recursos Naturais e o Desenvolvimento da Bacia da Lagoa Mirim (1977) e o anexo Protocolo para o Aproveitamento dos Recursos Hídricos do Trecho Limítrofe do Rio Jaguarão (1978).

d A ESEC, criada em 1986, participa de convenções globais de proteção, tais como Ramsar, além de ser Reserva da Biosfera pela Unesco (ALM, 2019).

e Próximo dali, no "lado" uruguaio, em um das poucas elevações da região, está o Fortín de San Miguel, construído no século XVIII por portugueses, a fim de vigiar e defender a Lagoa e adjacências de possíveis invasões.

f Tradução do termo inglês site, próximo à noção de local ou área. 
O Balneário Lago Merín, Uruguai, foi o único a ser construído às margens da Lagoa para fins de uso turístico, nos anos 1930. Está a cerca de $430 \mathrm{~km}$ de Montevidéu, e a cerca de $30 \mathrm{~km}$ da fronteira brasileira, por Jaguarão (RS). É o sítio, dentre os três, cujo nome remete ou confunde-se com o corpo d'água em si. Há no Balneário infraestrutura de hospedagem, além de comércio e serviços sazonais. Ali o fenômeno de segunda residência é mais evidente, por parte de alguns brasileiros, uruguaios ou com dupla cidadania. A atividade de pesca é hoje menos relevante, predominando o complexo arrozeiro.

Ao abordar as paisagens, buscamos entender o que significa para os sujeitos experenciar geograficamente a área a partir da intencionalidade turística (Pimentel, 2010). E, em vez de nos atermos a um discurso de potencialidades da Mirim para o turismo/lazer, optamos por partir do já existente, sobretudo em termos de representações da paisagem pelos turistas, bem como os usos turísticos estabelecidos, ou em ascensão.

\section{REFERENCIAL TEÓRICO: TURISMO E ESTÉTICAS DA PAISAGEM}

Nos estudos turísticos, a paisagem aparece em diferentes tendências: a) paisagem-objeto da cultura material (espaços físicos do turismo); b) paisagemrepresentação - imagens e imaginários construídos socialmente para transmitir valores, conceitos e significados, além de ideologias; c) paisagem-experiência - movimento, performances e respostas emocionais e sensórias aos objetos (Knudsen, Metro-Roland \& Rickly-Boyd, 2012; Knudsen, Metro-Roland \& Rickly-Boyd, 2014). Aqui, por (de)limitações de escopo, optamos por dar ênfase à paisagem-representação.

Tanto a acepção etimológica holandesa de lanschap (paisagem) quanto a versão anglicizada (inglesa) de landskip - tem a ver com uma cena a ser pintada - são oriundas da versão alemã de landschaft, a qual se relaciona com ideias de jurisdição, de espaços rurais ou regionais (Brook, 2014). A relação entre paisagem e estética tem sido duradoura (Knudsen, Rickly-Boyd \& Metro-Roland 2015). Interesses estéticos quanto à beleza das paisagens desempenharam papel pouco pronunciado nas práticas de sightseeing até os séculos XV e XVI (Adler, 1989).

Quanto à essência da paisagem e às ideias que a organiza, há pelo menos dez diferentes perspectivas, conforme Meinig (1979), hoje clássico da Geografia. De acordo com distintos olhares, a paisagem pode assumir feições de: natureza, habitat, artefato, sistema, problema socioambiental, fonte para investimentos (turismo e mercado imobiliário), ideologia, história, lugar e, por fim, estética. Nessa, há preocupação com o desempenho das qualidades artísticas pertencentes a algumas feições. Pintura e gravuras de paisagem conformam um gênero artístico peculiar a certas épocas e lugares, para o qual a paisagem é cenário e requer distanciamento para observála e retratá-la. Trata-se de uma vista penetrante, que busca significado implícito nas formas do cotidiano. A visão estética reside na crença de que há algo de essência, beleza e verdade na paisagem, tornando-a um mistério, pois porta significados que nos esforçamos para entender, mas que não conseguimos alcançar. Encontramos tal visão estética da paisagem além do domínio científico, ao possuir significados que ligam nossas psiques a um mundo infinito (Meinig, 1979). Desse modo, os estudos da paisagem ampliaram-se para muito além da Geografia na segunda metade do século XX, não 
causando estranheza o fato de terem atingido o campo do Turismo, cuja concepção de paisagens turísticas evolui em paralelo com a dos estudos da paisagem em geral (Knudsen, Rickly-Boyd \& Metro-Roland, 2014).

Os aspectos visuais e experenciais da paisagem que causam estranheza são empreendimentos centrais do turismo (Knudsen, Metro-Roland \& Rickly-Boyd, 2015). Assim, o turismo aprofunda a estetização do cotidiano (Franklin \& Crang, 2001), numa era em que tempo-espaços de turismo e cotidiano, lazer e trabalho, estão se tornando menos distinguíveis entre si. Para Sontag (2004), as câmeras fotográficas são as impulsionadoras de uma visão estética da realidade, na medida que permitem a todos emitir juízos sobre importância e beleza.

Concebemos o encontro com as paisagens como experiência estética dos sujeitos-turistas. Para Brook (2014), as experiências paisagísticas são balizadas por modos ou categorias estéticas, as quais possuem fontes de prazer distintos e atuam como componentes cognitivos de nossas heranças culturais ocidentais. Para Knudsen, MetroRoland e Rickly-Boyd (2015), a estética, por outro lado, serve para despolitizar e legitimar ideologias pela paisagem no turismo, ao perscrutar a sensibilidade e não o racional. Ainda, pelo fato de o turismo supor intepretação de signos no imagético paisagístico, os modos ou as categorias estéticas são relevantes como alicerces do processo de significação quando viajamos, organizando o que vemos, ao oferecer-nos verdadeiros paradigmas de visibilidade (Knudsen, Metro-Roland \& Rickly-Boyd, 2015).

O sublime parece como categoria positiva somente no século XVIII. Tratase de uma resposta emocional a feições grandiosas da natureza, como montanhas acidentadas, penhascos vertiginosos, mares tempestuosos, vulcões em erupção, turbilhões de água em uma cascata, efeitos dos raios, etc. (Brook, 2014; Knudsen, Metro-Roland \& Rickly-Boyd, 2015). A natureza é vista como hostil, misteriosa, causando sentimentos de solidão e desolação (Gastal, 2013). Majestoso e assustador, o sublime repele e fascina (Löfgren, 1999). Na interpretação kantiana, o sublime, justaposto ao belo, surge de nosso temor e admiração da natureza, de sua grandiosidade, infinitude, escuridão e violência. O chamado sublime dinâmico representa a contemplação de um terror quase esmagador e incontrolável, que conta como antecipação da morte, da qual, porém, acabamos nos livrando. Interessam os objetos mais fortes que o ser humano, capazes de nos causar dano: estes devem ser experimentados em primeira mão - traço do Romantismo. Para alguns românticos, esses sentimentos conectam-nos ao poder de um deus ou da própria natureza. (Brook, 2014; Knudsen, Metro-Roland \& Rickly-Boyd, 2015). O sublime esteve implicado com os movimentos literários românticos, que promoveram a redescoberta do sublime de escritos gregos, influenciando a prática do Grand Tour, em que homens jovens e nobres embarcaram para percorrer o continente europeu, incluindo cruzando os Alpes (Knudsen, Metro-Roland \& Rickly-Boyd, 2015). O turismo assim sacraliza o sublime europeu, em um discurso que persiste (Bell \& Lyall, 2008).

O desejo de imitar a natureza por meio da arte foi um gatilho da transformação do turismo por meio da linguagem da estética, à medida que conferia autoridade visual do turista, que consome paisagens durante suas viagens (Scarles, 2014). O Grand Tour 
trouxe consigo a centralidade do ocular, a hegemonia do visual, ou ocularcentrismo nas sociedades ocidental Moderna e Contemporânea (Löfgren, 1999; Banks, 2009; Scarles, 2014). No século XVIII, o sublime migrava da Filosofia e da Arte para as práticas turísticas, não ficando isento de (re)contextualizações; contudo a história do Turismo, centrada somente na evolução das grandes narrativas do Grand Tour, acaba marginalizando certas experiências e paisagens turísticas (Löfgren, 1999).

Segundo Bell e Lyall (2008), as práticas de turismo de aventura e de natureza, especialmente os esportes radicais, reativam e consomem a estética do sublime: essa categoria é a aura dessas modalidades de turismo. Em vez da visão passiva da natureza, os turistas passam a também envolverem-se em experiências corpóreas em um contexto de aceleração na/da natureza. Assim, a paisagem estática é retrabalhada em uma paisagem dinâmica. Não é fortuito que atividades de aventura/radicais ocorram em paisagens belas e/ou expressivas. Frequentemente, o cansaço físico de caminhar até o topo de uma elevação é recompensado pela visualização de uma (sublime) paisagem (Bell \& Lyall, 2008).

A categoria do pitoresco9, por sua vez, é um misto da herança pastoral grega com o sublime: toma emprestado a irregularidade rochosa/íngreme do sublime e a orientação ao pequeno/intimista do belo. Tal categoria do pitoresco atinge um equilíbrio entre o sublime, que testa nossos limites e propõe excitação, e o pastoral, que transmite segurança, mas que pode ser enfadonho. O pitoresco, então, valoriza a variedade, a complexidade, o selvagem e o decadente (Brook, 2014; Knudsen, Metro-Roland \& Rickly-Boyd, 2015).

Associado a isso, temos o gosto pela nostalgia, pelo idílico e pela vida rural, o que tem a ver com o melancólico (Löfgren, 1999), sentimento compartilhado entre o sublime e o pitoresco. O melancólico causa algum prazer, pela contemplação e reflexão, não se confundindo com depressão. O estado solitário acompanha a melancolia. Sendo emoção complexa e madura, o melancólico segue incompreendido (Brady, 2003).

De acordo com Löfgren (1999), a Arte ensinou os pioneiros do turismo, e foi o pitoresco, no século XVIII, que colaborou ao desenvolvimento dessa realidade, na medida em que atua como modo de selecionar, enquadrar e representar certas vistas, ensinando turistas a como olhar e sentir a paisagem. Na mesma época, mas sob inspiração do sublime, certos projetos de parques e jardins serviram para treinar a sensibilidade dos turistas pioneiros (Löfgren, 1999), ao inserirem rochas e pequenas quedas d'água, rejeitando a simetria formal, estando em oposição ao jardim francês, pois o pitoresco, em voga, não aceita(va) o perfeito demais, o artificial demais, ou o distante da natureza. Por outro lado, o pitoresco rejeita o sublime como selvagem, ameaçador e incontrolável (Brook, 2014; Knudsen, Metro-Roland \& Rickly-Boyd, 2015). Diante disso, a essa época o pitoresco era reconhecido como gosto mais propriamente feminino, ao passo que o sublime era mais propriamente masculino (Löfgren, 1999).

Essa categoria do pitoresco, contudo, remove o observador da paisagem, e é quase que inteiramente visual, ao contrário de outras categorias, como o sublime, que é mais sentimento. As relações de poder se dão de indivíduo para indivíduo (não

g Sua origem semântica está no pitoresco do Italiano e do Espanhol, designando o que poderíamos ou é digno de pintarmos (Gastal, 2013). 
de indivíduo para um deus, como no sublime). E, ao unir tradicional com moderno, é possivelmente uma das categorias mais relevantes ao turismo (Knudsen, Metro-Roland \& Rickly-Boyd, 2015), tendo embalado o turismo de massas em sua origem, nos primeiros destinos de montanha e litoral, fenômenos que ocorreram em concomitância (Boyer, 2003; Gastal, 2013). A crença nos efeitos restauradores de alguns cenários e a crescente orientação para um sightseeing de caráter estético acabaram por trazer um legado às convenções do turismo comercial que surgiria posteriormente (Adler, 1989).

O pitoresco pode ser considerado um sobrevivente: às vezes ridicularizado, sempre se redefinindo, mas ainda entre nós. É possível seguir sua trajetória por meio de mais de dois séculos, bem como seus ajustes a novas configurações, quando cruzou o Atlântico. Atualmente, o culto ao pitoresco lembra-nos da tensão do rotineiro e do improvisado nos mecanismos do turismo (Löfgren, 1999).

A paisagem do período do Romântico priorizou o pitoresco, que marcou a visibilidade do turismo, não somente nas origens, mas pelo menos até o século XX nas imagens turísticas (Gastal, 2013). Löfgren (1999) aponta que o olhar cênico (assim como romântico) há pelo menos dois séculos condiciona nossas seleções e nossos julgamentos das atrações e das paisagens do turismo, mecanismo esse nem sempre consciente.

As chamadas excursões pitorescas, no século XVIII, foram geradas pelos movimentos de contemplação da paisagem Romântico e Neorromântico (Löfgren, 1999; Minca, 2008), em que alguns objetos que já vinham sendo buscados, como pintura, escultura, etc., foram adicionados à busca pela natureza e pela paisagem (Adler, 1989). Nesse contexto, o "[...] empirismo contemplativo era base para a formação de um senso prático do mundo." (Pimentel, 2010: 121). A paisagem impunha-se na tentativa de domínio do espaço sensível e, paralelamente, a viagem convertia-se em exercício burguês para confirmação visual da natureza em tal domínio. A viagem pitoresca é resultado de uma relação entre uma "verdade do lugar", a Modernidade, e um método de observação meticuloso (Minca, 2008).

Urry (1996) classifica o olhar turístico como coletivo - locais que só parecem fazer sentido se mirados em massa de turistas, como grandes centros urbanos - e romântico - ressaltando, entre outros aspectos, a contemplação solitária. Neste, abordamos a construção do olhar do turista como um olhar eminentemente romântico, pois foi um movimento responsável por prolongar os então recém-inventados termalismo e alpinismo, de modo a alcançarem a descoberta de um exotismo espacial e temporal. A estética nascente do turismo passou a valorizar as chamadas bordas, como o campo, o mar e as montanhas, tidas como pitorescas (Boyer, 2003; Gastal, 2013).

Contudo, todas as categorias são alvo de críticas ético-políticas, especialmente em termos da concepção de paisagem e natureza como cênicas (Brook, 2014). A ciência do cênico representa a mais emblemática pictorialização das experiências na natureza, vista como um cartão-postal bidimensional, não concebida para cheirar, tocar ou ouvir, mas apenas para ser olhada (Löfgren, 1999). Além disso, o valor estético acaba não sendo diretamente comensurável com valores ecológicos, como biodiversidade e vice-versa (Brook, 2014). Contudo, as sensibilidades do sublime e do pitoresco foram em certa medida valorizadas pelo caminhar por meio das paisagens, incentivando os 
sujeitos, turistas ou não, a que tivessem suas experiências corporificadas da paisagem, ou seja, que possuam raízes somente no visual, mas também em outros sentidos humanos (Löfgren, 1999; Brook, 2014). Assim, uma estética mais participativa, que se opõe a uma visão distanciada e desinteressada, solicita o envolvimento corpóreo no mundo vivido (Brook, 2014).

A partir das qualidades sentidas, organizadas em categorias, e refletidas subjetivamente, somos capazes de emitir descrições e juízos estéticos. Alguns desses podem ser superficiais ou idiossincráticos, outros, intersubjetivamente experenciados (Brook, 2014), sob descrição ou avaliação, cenários, situações e paisagens são valoradas (Löfgren, 1999). O juízo estético, no âmbito do turismo, é tratado como juízo turístico. Todo enunciando "isso é belo" é uma forma de juízo subjetivo que compele à concordância dos outros turistas (Knudsen, Metro-Roland \& Rickly-Boyd, 2015).

A maior parte dos motivos que levaram ao desejo de se fixar as percepções visuais em imagens dizem respeito a novas atitudes em relação à paisagem (Urry, 1999), especialmente no século XIX. Este trabalho segue uma tendência na qual se busca compreender o porquê de os sujeitos terem preferências por determinadas paisagens, bem como aferir os significados que atribuem essas paisagens turísticas - conformando um paradigma "cognitivo" ou "experiencial" (Jacobsen, 2007), passando do objeto para a relação do sujeito com esse, distinguindo-se de tendências objetivistas, que, por meio do olhar de especialistas e com finalidades restritas ao planejamento, busca analisar os aspectos psico-físicos.

As imagens englobam um largo espectro de fenômenos visuais (Nöth, 1995). A representação visual é algo em si, não é uma mera substituição de algo não visto objeto a que se refere. Onipresentes, e sensorialmente proeminentes, as imagens podem ser empregadas em todos os estudos da sociedade, sendo que alguns conhecimentos são produzidos somente a partir desse suporte (Banks, 2009).

Pautando-nos pela Semiótica, verificamos que há imagens gráficas (como as fotografias), mas há também as ópticas, perceptuais, mentais e verbais. Ao evocarem a semelhança com o objeto representado, são geralmente classificadas como ícones (signos icônicos) das realidades que retratam, mantendo inalterados certos aspectos do objeto representado (Nöth, 1995).

A fotografia analógica, impressa/revelada, é produzida quase que mecanicamente a partir de um processo físico-químico no qual o (objeto) referente é a causa do significado pictórico, isto é, um índice, que é signo de contiguidade física e existencial do objeto, para este apontando (Nöth, 1995). "A indexicalidade predomina na fotografia como um vestígio, como protocolo de uma experiência, como uma descrição, um testemunho." (Santaella \& Nöth, 2011: 113). Diante disso, a imagem fotográfica pode também ser um ícone indexical (Santaella \& Nöth, 2001).

Mas em fotografia há também alterações nas feições em relação ao objeto análogo, tais como: a perda da terceira dimensão, a limitação de uma moldura, a alteração da cor e da superfície granular estruturante da figura, a mudança de escala e a perda dos estímulos não visuais. A arbitrariedade da percepção fotográfica, passível de distorções e manipulação da realidade, diminuem a iconicidade, conferindo ao 
fotógrafo a capacidade de criar a realidade que fotografa (Nöth, 1995; Santaella \& Nöth, 2001), aproximando-se do símbolo. Como signo de arbitrariedade e lei, permite inúmeras réplicas ou cópias. (Nöth, 1995). Com as câmeras de nossos smartphones, por meio de efeitos e filtros de aplicativos e/ou mídias sociais, nos são possibilitados inúmeros recursos que reforçam a arbitrariedade da fotografia digital, ao mesmo tempo em que conferem maior autoria ao sujeito-fotógrafo, entre outros aspectos, indo ao encontro da fotografia como gênero artístico.

A gramática pictórica das imagens busca elucidar relações, tais como figurafundo, contrastes de luz, etc. Quando comparadas aos textos verbais, as imagens são consideradas polissêmicas. Diante disso, considerar o contexto das figuras, ou a sequência em que aparecem, serve para reduzir a abertura interpretativa inerente a elas (Nöth, 1995).

Quanto às legendas das fotografias, que são consideradasíndices pela Semiótica, essas podem assumir caráter declarativo e diretivo (ancoragem), ou estarem em uma relação com a imagem (revezamento), segundo linguagem barthesiana, conforme apontado em Nöth (1995). Sontag, (2004:125), contudo, alerta: "As legendas tendem a exagerar os dados da visão; mas nenhuma legenda consegue restringir, ou fixar, de forma permanente, o significado de uma imagem.". Elas podem ser consideradas interpretações limitadoras da fotografia à qual está ligada (Sontag, 2004).

Isto posto, sintetizamos que a fotografia apresenta paradoxos. Como análoga, apresenta objetividade, transmitida a partir de uma mensagem denotativa, não codificada. Por outro lado, a fotografia, digital ou impressa, pode ter sido tratada profissional, estética e ideologicamente, a partir de códigos que conformam a conotação (Nöth, 1995; Santaella \& Nöth, 2001).

\section{PROCEDIMENTOS METODOLÓGICOS}

O uso de imagens configura uma técnica mais adequada em alguns estudos do que em outros. Podem ser estudadas as imagens produzidas e consumidas pelos sujeitos pesquisados, ou seja, as fotografias por eles sacadas, realizando a conexão da imagem como o contexto social (Banks, 2009). As técnicas empregadas envolvem fontes secundárias, disponíveis em arquivos ou repositórios, cujos dados podem ser avaliados por análise de conteúdo, num primeiro momento (Scarles, 2014). É comum a associação da análise de conteúdo com a Semiótica (Banks, 2009).

Pautamo-nos pela pesquisa qualitativa, que visa, entre outros elementos, assegurar que os métodos e as teorias são apropriados (o objeto define a metodologia), bem como garantir reflexividade do pesquisador e da pesquisa, bem como dados em si mesmos. A pesquisa qualitativa é orientada pela visão dos sujeitos pesquisados, e a quantitativa, pelo pesquisador, segundo Flick (2009).

Procuramos ir ao encontro do preconizado uso de dados visuais, evitando a reatividade comumente presente em entrevistas e observações, buscando fazer uso dos documentos que "estão aí", os quais são gerados de modo relativamente espontâneo. Após avaliação e adaptações, optamos pela tendência no Turismo, segundo a qual se 
utilizam fotografias pré-selecionadas, buscando entender como as pessoas categorizam, descrevem e avaliam as paisagens estudadas (Jacobsen, 2007).

Pesquisas recentes têm utilizado plataformas como Flickrh, em substituição ao estudo de sites institucionais, fôlderes e guias de viagem (Picazo \& Moreno-Gil, 2019). Neste trabalho, ao adotarmos o Flickr, buscamos sobretudo o olhar profissional que era predominante nos inícios da plataforma, e até mesmo obter certa análise longitudinal, uma vez que podem ser encontradas fotos clicadas no intervalo de mais uma década.

"Um problema peculiar é a questão do enquadramento - o que está na fotografia, ou que está sendo focalizado, o que é deixado de fora? - e da medida em que o estilo estético pessoal do fotógrafo determina o conteúdo da foto." (Flickr, 2009: 223). Isso é de particular interesse para nossas análises, uma vez que paisagem se trata de seletividade, enquadramento e subjetividade. Como que em um diário fotográfico: "É o sujeito quem deverá decidir sobre quais os aspectos ou eventos que merecem ser fotografados, e não o pesquisador." (Flick, 2009: 221). As imagens produzidas pelos sujeitos (turistas) traduzem os seus entendimentos e suas representações (Banks, 2009).

Procuramos estar atentos ao contexto técnico-informacional vigente, na medida em que a internet é tida "[...] como um tipo de ambiente social ou cultural na qual as pessoas desenvolvem formas específicas de comunicação ou, às vezes, identidades específicas." (Flickr, 2009: 246). O contexto da imagem informará sua leitura (Banks, 2009). Aqui tratamos de um suporte específico (fotografia digital) em um ambiente igualmente peculiar (repositório fotográfico), em que ocorre a visibilidade e as trocas entre usuários.

A tomada de decisão quanto ao corpus de pesquisa ocorreu mediante distintos níveis de amostragens. Houve: amostragem de casos (quais fotos utilizar?), amostragem do material (quais fotos deveriam ser armazenadas e analisadas?); amostragem interna do material (quais partes das fotografias devem ser interpretadas?); e amostragem de apresentação (quais fotos ou partes de fotos se revelam promissoras na demonstração das descobertas?), ou seja, perpassando as etapas de coleta, interpretação e apresentação dos resultados (Flick, 2009).

O trabalho seguiu uma coleta completa, cuja amostragem delimita as fotografias passíveis de inclusão, a partir de critérios de relevância, em detrimento das fotografias que são excluídas de antemão. A extensão e as características do universo não são conhecidas, nem definidas de antemão. Também houve definição gradual da amostra de pesquisa, ou seja, uma amostragem teórica, consoante à pesquisa qualitativa, cuja decisão é tomada na coleta e também na interpretação dos dados. Diferentemente da amostragem aleatória ou estratificada, selecionaramse as fotografias que pudessem enriquecer o desenvolvimento teórico (Flick, 2009). As relações entre questões epistemológicas e as da pesquisa empírica são objeto de reflexão, uma vez que teoria e metodologia aqui se retroalimentam (Banks, 2009).

$\mathrm{Na}$ busca pelas fotografias a serem estudadas, a partir de levantamento realizado em 27 de julho de 2019, ocorreu alto índice de descarte de fotografias

h O Flickr surgiu em 2004, foi por 13 anos propriedade do Yahoo, posteriormente vendido à SmugMug. Embora aparentemente tenha perdido espaço para outras recentes redes sociais, o foco recente da plataforma é ser repositório de compartilhamento de fotografias de profissionais e amadores, e menos uma rede social. O serviço segue ativo, apesar dos percalços com a adaptabilidade necessária às fotografias de dispositivos móveis (Alecrim, 2018). 
$(87,83 \%)$, e isso possui diversas razõesi. Fotografias não consideradas de paisagem, ou que apresentassem a paisagem pelo menos como um fundo, foram descartadasj. Um vídeo foi desconsiderado. Importam, aqui, as referências sígnicas às paisagens lacustres estudadas, de modo que pudessem ser identificas como tais. Fotos que apareciam em mais de um sítio foram incluídas em somente em um deles, bem como fotos de cenas repetidas, também consideradas uma única vez.

No caso do termo "Capilha", ele foi eficiente. Contudo, foram encontradas fotografias da ESEC do Taim, que, embora próximas, fugiam ao escopo espacial e temático proposto. Tal era averiguado por meio dos próprios elementos da paisagem ou, ocasionalmente, da rotulagem dos fotógrafos. Os termos mais problemáticos foram os relativos ao Porto Pindoramak. Consideramos não uma amostragem, mas sim um corpus da pesquisa ou, ainda, o universo das fotografias de paisagem dos três locais estudados disponibilizados no Flickr, de acordo com os critérios de inclusão/exclusão. No corpus das 65 fotos, 24 são do sítio uruguaio, e as demais, 41, são dos sítios brasileiros. Há proporcionalidade no que se refere ao tamanho da costa lacustre em cada um dos países (é maior no Brasil). Foi feito download das fotos que permitiam essa função, e/ ou pressionada a tecla de print screen de modo a armazená-las e analisá-las. Contudo, somente as fotografias cujos autores permitiam download são apresentadas aqui.

Buscamos dar centralidade à fotografia, embora incluindo elementos textuais referentes à descrição/legenda, redigidos pelos próprios sujeitos-operadores, quando esses elementos estiveram presentes. Oito legendas do sítio uruguaio e 24 dos sítios brasileiros também foram analisadas, a fim de entender a conexão entre texto e imagem realizada pelos autores. Os comentários não foram analisados. A ideia foi complementar imagem com o texto.

Então, empreendemos análise de conteúdo, por meio do software NVivo Pro - QSR International, a partir de uma combinação de codificação aberta e teórica do material textual e visual. Denotação e conotação são comuns nos estudos de imagem dos destinos (Hunter, 2016; Picazo \& Moreno-Gil, 2019). Forma e conteúdo da imagem são só distinguíveis analiticamente (Banks, 2009). Signos conotativos carregam signos de nível mais alto (Rose, 2001).

Embora as definições mais tradicionais classifiquem a análise de conteúdo como técnica estritamente quantitativa, ela é, entretanto, uma técnica de pesquisa usada para avaliar sistematicamente os conteúdos real e simbólico de todas as formas de registros 
de comunicação. A análise de conteúdo é pertinente ao contexto multimétodo, a partir do qual podemos aumentar a validade dos resultados e a minimização de possíveis vieses. Assim, torna-se promissor elemento tanto da análise hermenêutica quanto da semiótica (Hall \& Vallentin, 2005).

A preocupação central da análise qualitativa de conteúdo, embora essa buscasse em primeiro lugar contar o que pensamos estar vendo (Rose, 2001), foi a de que as categorias/códigos que emergissem do conteúdo analisado fossem exaustivas - todo aspecto da imagem relacionado à pesquisa deve estar coberto por pelo menos uma categoria -, mutuamente excludentes, e esclarecedoras; além disso, que não fossem ambíguos, o que garantiria maior replicabilidade na codificação. Ainda, os códigos são considerados válidos ao explicitarem suas ligações com textualização e contexto (Rose, 2001).

Quanto à denotação e à conotação, já referidas na seção anterior, cabe esclarecermos que buscamos partir da denotação dos motivos fotografados para a conotação estética do conjunto paisagístico das fotografias.

\section{APRESENTAÇÃO E DISCUSÃO DOS TRABALHOS}

Há boa cobertura de fotografias, de um sítio ou outro, dentro do período analisado (2000-2018). Verificamos que os autores' não são os mesmos dos três sítios, o que indica que os visitantes não frequentam a Lagoa como um todo, e que os sítios podem estar isolados entre si como destinos. Considerando as fotografias, os autores não retornam aos locais fotografados, ou não os fotografam ao longo do tempo, com raras exceções. Foram identificadas 20 categorias/nós diferentes, de modo a esgotar o material encontrado. A Tabela 1 apresenta a narrativa externa das imagens (Banks, 2009), arrola as categorias encontradas, em ordem alfabética, e a respectiva frequência de cada uma delas, de acordo com os sítios estudados.

Notamos mais autores com sobrenomes hispânicos em Lago Merín, situação intermediária em Santa Vitória do Palmar (mesmo que se dissessem moradores da cidade brasileira), e maior incidência de sobrenomes lusos (presumivelmente brasileiros) na Vila da Capilha, com algumas menções de origem de locais mais distantes no Brasil, o que não ocorre em Santa Vitória. 
Tabela 1 - Nós/categorias identificadas nas fotografias

\begin{tabular}{llcccc}
\hline & \multirow{2}{*}{ Nós/categorias } & \multicolumn{3}{c}{ Sítios } & Total \\
\cline { 3 - 5 } & & Capilha & $\begin{array}{c}\text { Porto de Santa } \\
\text { Vitória }\end{array}$ & Lago Merín & \\
\hline 1. & Águas & 14 & 14 & 22 & $\mathbf{5 0}$ \\
2. & Ambiente constrúdo & 15 & 17 & 8 & $\mathbf{4 0}$ \\
3. & Animais de estimação & 0 & 0 & 2 & $\mathbf{2}$ \\
4. & Areia e falésia & 9 & 0 & 17 & $\mathbf{2 6}$ \\
5. & Barco de pesca & 5 & 2 & 1 & $\mathbf{8}$ \\
6. & Céu claro & 14 & 6 & 12 & $\mathbf{3 2}$ \\
7. & Céu escurecido & 1 & 2 & 7 & $\mathbf{1 0}$ \\
8. & Esporte & 1 & 0 & 0 & $\mathbf{1}$ \\
9. & Fauna & 0 & 2 & 0 & $\mathbf{2}$ \\
10. & Meios de transporte e aventura & 5 & 0 & 0 & $\mathbf{6}$ \\
11. & Noite & 1 & 0 & 1 & $\mathbf{2}$ \\
12. & Objeto de barco & 0 & 1 & 0 & $\mathbf{1}$ \\
13. & Panorâmica, foto & 0 & 1 & 1 & $\mathbf{2}$ \\
14. & Pessoas & 3 & 7 & 6 & $\mathbf{1 6}$ \\
15. & Pôr do sol & 8 & 6 & 1 & $\mathbf{1 5}$ \\
16. & Preto e branco, foto & 1 & 1 & 1 & $\mathbf{3}$ \\
17. & Texto & 0 & 2 & 0 & $\mathbf{2}$ \\
18. & Vacationscape & 0 & 0 & 20 & $\mathbf{2 0}$ \\
19. & Vegetação & 16 & 15 & $\mathbf{5 3}$ \\
20. & Vertical, foto & 0 & 1 & 0 & $\mathbf{1}$ \\
\hline
\end{tabular}

Fonte: Elaboração dos autores (2019).

As categorias representam os elementos encontrados e também os motivos em torno dos quais pudemos reunir as imagens. O tema "águas" foi um dos mais frequentes, ora calmas, ora com ondulações. O motivo agrupa não só a Lagoa em si, mas, ocasionalmente, canais e piscinas que se formam. A legenda de uma fotógrafa faz a comparação: "Quem diz que não é o mar?". Ou, ainda, fala do prazer com as águas e revelando uma intenção: "É meu lago preferido, imenso, azul, falta ter uma casinha ao lado [...]" (Flickr, 2019, tradução nossa). O motivo "vegetação" também é frequente (53) e abrange desde gramíneas, passando pelos estratos arbustivos, até os arbóreos (menos comuns). Uma das composições trouxe como legenda um detalhado conhecimento botânico, cuja fotografia é do tipo documentário, ou seja, para fins de monitoramento ou conhecimento do local (Bell, 2010). As duas primeiras legendas parecem de tipo revezamento, e a última predomina o caráter declarativo e diretivo, ou seja, de ancoragem.

A paisagem é frequentemente clicada com céu claro e luz oblíqua e, menos comum, com céu encoberto. O pôr do sol, com luz zenital, aparece em uma fração expressiva das fotos (15 de 65), porém mais frequentemente no "lado" brasileiro. Apenas duas fotografias foram clicadas à noite. Quando aparece o céu, repete-se por vezes a solução composicional "areia, água e céu/sol", um terço para cada, em geral ao pôr do sol, como uma paisagem arquetípica. Apesar da baixa interferência 
antrópica, elementos do ambiente construído (igreja, residências, mobiliário urbano, passarela e passeios) são frequentes (40), especialmente na Vila da Capilha e no Porto de Santa Vitória, e menos em Lago Merín, apesar de ser o local mais ativo em termos de turismo. Areias, dunas e falésia são motivos frequentes (26), ocorrendo no Balneário de Lago Merín e na Praia da Capilha. A presença e a ausência de pessoas também são codificadas (Picazo \& Moreno-Gil, 2019). Turistas sob o cenário paisagístico aparecem relativamente pouco: em apenas 16 das 65 fotografias. Na Vila da Capilha, aparecem em apenas três das 24 fotos. Deixar a fotografia de uma praia vazia permite que nos coloquemos nessa imagem, conjuntamente com nossos amigos e nossa família, o que não acontece numa fotografia de praia cheia (como Lago Merín); assim, paisagens desérticas (como a Capilha) reforçam a noção de escape e liberdade, lugar-comum no turismo (Tressider, 2011 1). Não raro, aparecem em cenas do veraneio em família, que são as fotografias típicas do álbum de família (Bell, 2010), em que pessoas são mais importantes que a paisagem. A foto de um bebê brincando próxima à água tem a seguinte legenda: "CRIANÇAS NÃO (2004:125) SENTEM FRIO? Não devemos explicar nada a uma criança. É preciso maravilhá-la" (Flickr, 2019). Nessa passagem, observamos a relação de imagem e texto, na legenda, como sendo de revezamento, ou seja, uma relação de complementação predominante, sem retirar a ambiguidade.

Quando há pessoas, elas estão realizando poses, participando de uma vacationscape e/ou de práticas de balneário (banho de sol ou banho na Lagoa) e, menos frequentemente, praticando esportes ou atividades ativas. Nenhuma fotografia de esportes aquáticos foi encontrada, embora Varnier (2017), no estudo do Porto, enuncie as motos aquáticas. Mesmo em fotografias do balneário sem pessoas, as vacationscapes se fazem presentes, pois são signos de um veraneio ocorrido, ou seja, no inverno, são remanescentes de uma cultura (material) que por ali passou (Löfgren, 1999). A categoria de vacationscapes atenta às práticas e às performances do veraneio em sítios de hedonismo, como os balneários, ocorrendo espaços mais lotados de pessoas, o que aparece em Lago Merín (20). Assim, a fotografia turística não se trata somente de olhar paisagens de modo distanciado, mas sim de engajar-se com elas corporealmente, agindo, posando, brincando (Larsen, 2006).

Barcos de pesca artesanal são motivo relativamente frequentes (8), mas somente no "lado" brasileiro, compondo cenários com águas e céu. Diferentemente dos barcos como meios de trabalho, aparecem meios de transporte dos turistas (6), geralmente vinculados ao turismo de aventura, como jipes e motocicletas, o que ocorre, sobretudo, na Vila da Capilha. Esses aspectos de aventura dialogam com os sítios de hedonismo e vacationscapes, mas aqui optamos por uma categoria em separado. Em termos composicionais, a tomada geralmente é da praia para a água e o céu (especialmente a Capilha), somente uma capturou a falésia. Nenhuma foto foi tirada da água, a partir de embarcações. A frente da igreja da Capilha é um ícone dessa localidade. Em Lago Merín, a fim de capturar a praia, as fotografias são muitas vezes da linha da costa. No porto, parece haver duas paisagens icônicas: uma do terminal, aparecendo menos a Lagoa e o pôr do sol, e outra, do trapiche, privilegiando-os. Podemos falar das imagens como uma sinédoque (tipo de conotação), por meio da qual um todo imagético representa uma parte do representado (Rose, 2001). Os aspectos fotografados são 
sinédoques do todo representado por esses locais geográficos, ou, ainda, partes do turismo/lazer local-regional, proporcionado pela Lagoa, ora são tomados como todo. Quando falamos nas denotações de aventura e diversão, por exemplo, estamos falando dos significados conotativos metonímicos (Rose, 2001). A fauna é pouco ressaltada (apenas duas ocorrências de aves no Porto). Fotos panorâmicas, em preto branco e vertical são ocasionais. Não apareceram menções textuais ou imagéticas ao Cerro de San Miguel e a margem oeste da Lagoa, que, visíveis do Porto, formam uma paisagem transfronteiriça (Varnier, 2017). Para nós, além de levarmos em conta o que aparece ao olhar do turista, é relevante o que é invisível a ele, o que pode estar relacionado à leitura estética da paisagem.

\section{INTERPRETAÇÃO ESTÉTICA DAS PAISAGENS DA LAGOA MIRIM}

A amostrageme a categorização dos dados, que obedecem a uma metodologia formalista e sistemática, antecedem à análise de cunho interpretativo (Banks, 2009), delineada nesta seção. Ao lado de outras intencionalidades e tipologias de fotografia turística, sobressai-se a composição fotográfica que busca mérito técnico ou estético (Bell, 201 1). Contudo, a relação estética não é meramente contemplativa; ao contrário, boa parte da experiência turística resultaria em produção ou representação de caráter estético - cultura visual -, com destaque para o suporte fotográfico (Pimentel, 2010).

A Figura 2 apresenta fotografias-chave da Vila Capilha nesta pesquisa.

Figura 2 - Fotografias-chave da Praia/Vila da Capilha

1

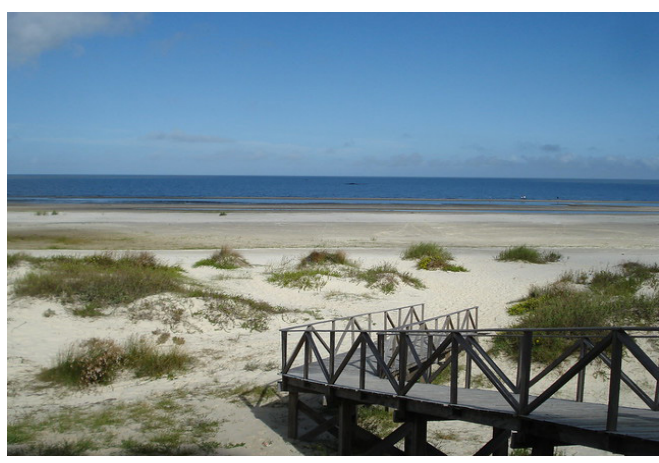

2

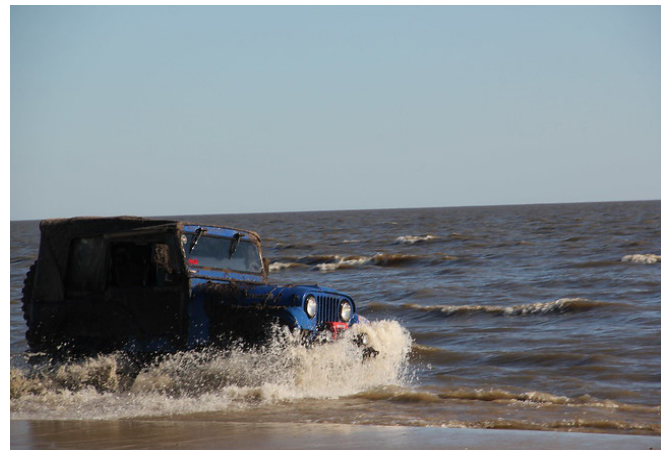

3

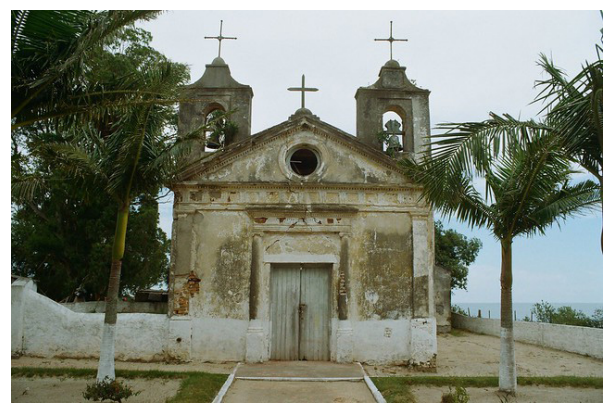

Fonte: 1- D. Tartari (2012), 2- P. Ramos (2011) e 3- G. Pinheiro (2018), disponíveis em Flickr (2019). 
A Figura 3 apresenta fotografias-chave do Porto de Santa Vitória de Palmar neste trabalho.

Fig. 3. Fotografias-chave do Porto de Santa Vitória do Palmar

1

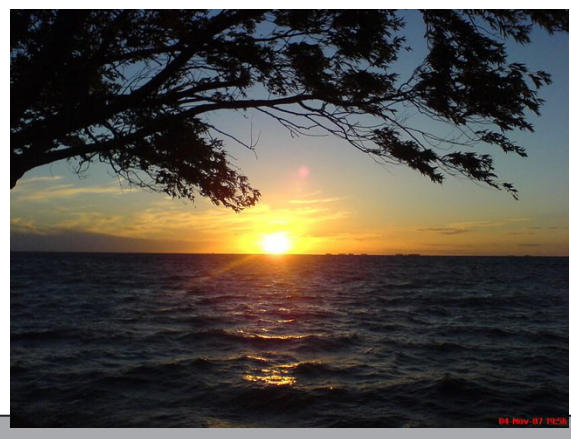

2

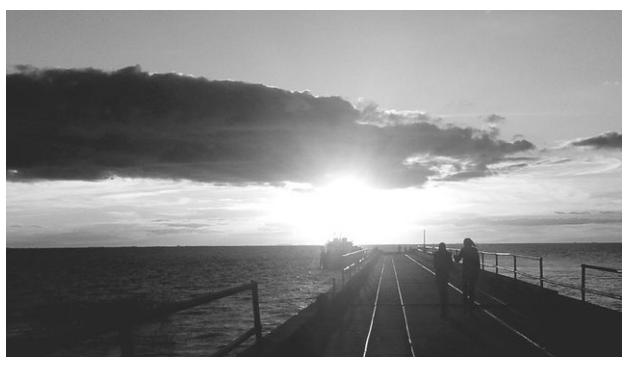

3

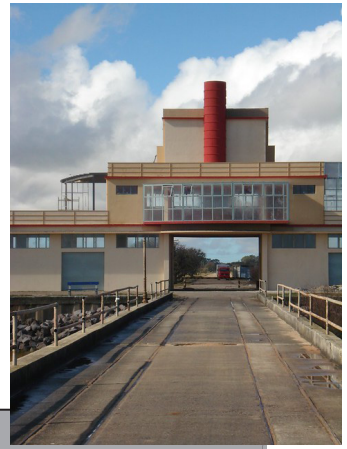

Fonte: 1- N. N. Lemes (2011), 2- R. Garre (2013) e 3-"a.dudu" (2008), disponíveis em Flickr (2019).

A Figura 4 apresenta fotografias-chave de Lago Merín neste estudo.

Fig. 4. Fotografias-chave de Lago Merín

1

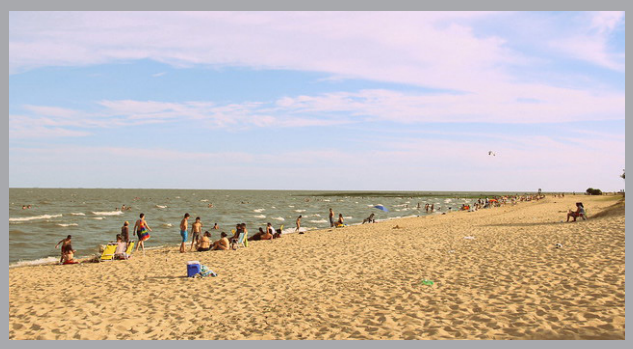

2

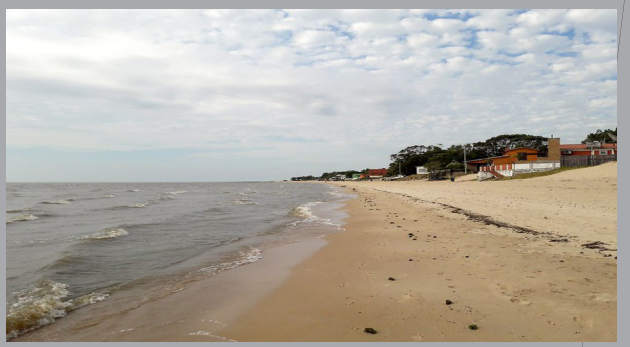

3

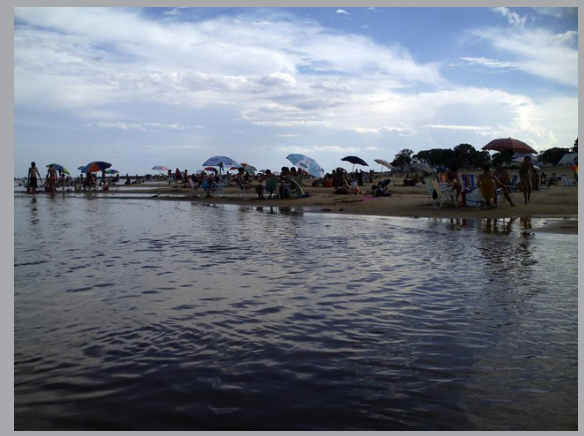

Fonte: 1- D. Tartari (2012), 2- G. Pinheiro (2018) e 3- P. Ramos (2011) e, disponíveis em Flickr (2019).

A água, como elemento-chave da paisagem lacustre, é clicada pelos turistas estando calma ou com algumas ondulações do vento (características da lagoa e da sua região). Potocka (2013) constata que o paraíso frequentemente retratado envolve a existência de água, e que oásis é o termo que se refere ao local onde a água é 
encontrada. A imensidão de águas da Lagoa Mirim, comparável à do mar, e não se tratando de um reservatório artificial, traz como conotação a natureza magna, que é reforçada pelo fato de essa experiência ser considerada irreprodutível (Pimentel, 2010). A atmosfera prístina da paisagem é uma categoria prevista em estudos de análise pictórica de imagem dos destinos (Picazo \& Moreno-Gil, 2019). Associada a isso, uma das fotógrafas comenta com poesia, segundo ela, de Manuel Bandeira: "Quero sentir a delícia das coisas simples.". Áreas de natureza selvagem e aparência estéril, que foram fontes de temor, têm-se transformado em cenários e paisagens para consumo visual (Urry, 1999).

Varnier (2017: 99) avalia a Lagoa Mirim: "A forma linear plana e única da lagoa, e as linhas formadas pelas margens da mesma em contato com a vegetação, apresentam pouca diversidade." As águas da Lagoa Mirim estão retratadas ora claras, ora escurecidas. Segundo Potocka (2013), a vista da água, da luz sendo refletida na sua superfície, propiciaria ao ser humano a reflexão sobre si mesmo e o mundo límpido ou de cores claras, a água seria percebida e sentida de modo positivo, enquanto que nublada ou escura, evocaria respeito e estimularia o medo. A autora, (2013) utilizando eye-trackingm, apontou que a água é elemento de atratividade, porém os pontos para os quais o olho dos turistas mais se direcionam são aqueles da linha de contato entre água e terra, ou água e céu, ou seja, na linha da orla, buscando diferenciação de linhas e texturas, indo ao encontro dos dados encontrados. Ainda segundo a autora (2013), a vasta superfície de água dos lagos, ao ser considerada monótona, pode ser avaliada negativamente.

Assim como as águas, o céu fotografado, na maioria das vezes, está claro (com uma atmosfera vibrante), mas algumas vezes está nublado, encoberto ou até mesmo com neblina (atmosfera mística). O fenômeno do pôr do soln, que representa o jogo de pelo menos dois elementos - fogo e ar (atmosfera), mas a vista pode envolver a porção da água e uma linha de terra - é elemento notável. "Nas primeiras décadas da fotografia, esperava-se que as fotos fossem imagens idealizadas. Ainda é esse o objetivo da maioria dos fotógrafos amadores, para quem uma bela foto é uma foto de algo belo, como [...] um pôr do sol." (Sontag, 2004: 40).

Novamente nos referindo à legenda com explicação detalhada da vegetação, Brook (2014) ponderaria que conhecimento científico pode valorizar nossa apreciação da paisagem, mas também pode nos deixar de fora do deleite estético ao reclamar a nossa atenção para outros aspectos: ao assumirmos a postura de um botânico, perdemos alguns detalhes sensoriais da experiência estética da paisagem. Ainda no quesito "vegetação", chamam a atenção as árvores secas e retorcidas que foram fotografadas. A irregularidade da forma é um traço do pitoresco. A característica de uma paisagem aberta, conforme fotografada, levanta questionamentos sobre a atratividade que exerce sobre os sujeitos. A teoria dos refúgios afirma que a savana é o ambiente no qual o ser humano sente-se seguro, dada uma adaptação no processo evolutivo. Nesse ambiente, podemos nos esconder, mas ainda assim sermos capazes

m Buscou rastrear e gravar a atividade ocular do ser humano, a fim de definir os elementos que os turistas percebem em uma paisagem lacustre. Levou em conta o tempo de fixação do olho em determinado objeto ou linha. A técnica foi seguida da aplicação de questionário. A amostra foi de 36 indivíduos (Potocka, 2013).

n Avaliado como categoria à parte no estudo do Porto realizado por Varnier (2017). 
de observar. Isso também tem a ver com o pitoresco. A areia, por sua vez, aparece de diversos modos: fina ou grossa, clara ou escura, seca ou molhada, em colmos, etc. A areia é expressiva, pois é representativa do ambiente das praias, zona de contato ou "fronteira" entre o corpo d'água e a terra, atraindo a atenção dos seres humanos (Tuan, 2012).

No item "ambiente construído", aparecem em destaque a igreja da Capilha (que aparentemente necessita restauro) e o atracadouro do Porto (que é infraestrutura em desuso como tal). O edifício do porto foi retratado em 2007 antes da sua revitalização. Uma fotografia da capela, tirada em preto e branco, traz como legenda a capela "dramática". Atracadouros e ruínas são exemplos da estética do melancólico (Brady, 2003). "A fotografia estende a descoberta da beleza das ruínas feitas pelos literatos do século XIX em um gosto genuinamente popular [...] ruínas românticas" (Sontag, 2004: 94), até surgirem inclusive ruínas artificiais, a destacar o cunho histórico da paisagem (Sontag, 2004). Falamos anteriormente dos espaços vazios, que correspondem a uma atmosfera romântica ou intimista, em contraposição com espaços lotados e/ou com atividades ativas de lazer (Picazo; Moreno-Gil, 2019). Isto porque a interpretação de imagens fotográficas, ao considerar as leituras preferentes, pode apontar a natureza ideológica da relação entre imagem e seu observador, ou seja, as modalidades de recepção das imagens (Rose, 2001).

Conforme analisamos, sob a Praia da Vila Capilha há um olhar romântico, diferentemente da vacationscape de Lago Merín, em que o olhar coletivo é mais frequente (Urry, 1996). O Porto é um meio-termo, embora predomine o romântico e o pitoresco.

Pelo menos quatro fotografias na Capilha apresentam experiências cênicas do dirigir, (categoria prevista em Picazo \& Moreno-Gil, 2019). Jipe vencendo as águas da margem ou a lama do local são claros exemplos de aventura, de aceleração e de desafio à natureza grandiosa, subjacentes à estética do sublime, na paisagem e na prática turística. Na falta de pontos mais altos para observação, naturais ou construídos, aparecem algumas fotos panorâmicas. Esse tipo de visão teria surgido da "encenação do sublime": as qualidades "dramáticas" da vastidão se tornaram critério central. A posição elevada, se disponível, representaria o poder da natureza diante da insignificância do ser humano (Löfgren, 1999: 43). Como contraste, os barcos de pesca artesanal, das comunidades do Porto e da Capilha são meios de trabalho e sobrevivência dos residentes, e objeto de prazer estético do pitoresco por parte de fotógrafos e turistas. A estética não está somente no objeto, tampouco somente no sujeito, mas sim na interação entre eles. Segundo Brook (2014), pessoas que habitam as áreas podem não estar vendo as qualidades estéticas, ou do contrário, podem estar profundamente cientes dessas, de um modo que um outsider não conseguirá experenciar. De acordo com MacCannell (2011), os turistas estão predispostos a admirar os cenários "pitorescos", entre eles os lugares onde se pode verificar pouca evidência da presença humana e/ou cuja evidência pertença ao passado. Tais paisagens nos forçam uma parada, engendrando sentimentos de calma, paz e consolo. São buscadas por turistas que procuram alívio dos barulhos e das demais agressões da vida urbana (MacCannell, 2011). Nesse sentido, a paisagem pitoresca pode funcionar como o Outro (sujeito) do/no desejo do turista. Portanto, 
a paisagem é o que fica entre o sujeito e o Outro, mediando a experiência entre eles. A alteridade, perseguida pelos turistas em suas viagens, não se refere apenas a sujeitos, mas também a paisagens e lugares (MacCannell, 2011). "O fotógrafo é um superturista, uma extensão do antropólogo, que visita os nativos e traz de volta consigo informações sobre o comportamento exótico e os acessórios estranhos deles" (Sontag, 2004: 54). Os barcos de pesca artesanal são o backstage das comunidades residentes, que, de certo modo, são trazidos para o frontstage pela fotografia e pelo turismo, na busca pelo autêntico, embora não necessariamente encenado, costuma tender para um autêntico turístico (MacCannell, 1999). Os estudos turísticos têm privilegiado o exótico e o estranhamento. Diante disso, há que sempre se 'deexotizar' o turismo (Franklin \& Crang, 2001).

A perspectiva linear, com ponto de fuga, dispositivo óptico por meio do qual um objeto em três dimensões é percebido em apenas duas (Gastal, 2013), como uma regra de composição de figuras (Banks, 2009), se faz visível na maior parte das fotografias, corroborando com a literatura. Poucas imagens procuraram desafiar tal disposição, que se trata de um código visual (Banks, 2009). O uso da perspectiva linear, verificado nas imagens coletadas, foi aumentado pelas concepções românticas de paisagens sublimes e de aparência estéril (Urry, 1999).

O sujeito turístico possui um olhar ocidental, perspectivado, remanescente do Renascimento. É um sujeito que se concebe como fonte centro de tudo, contudo falha ao não reconhecer que se outorga certa superioridade e primazia no/do seu olhar (MacCannell, 2001). Afora os códigos, analisamos alguns processos sociais, como as concepções de natureza e estética subjacentes e, em menor medida, a força intencional ou de agência de cada fotógrafo (Banks, 2009).

Podemos, ainda, falar das imagens como uma sinédoque, por meio das quais um todo imagético representa uma parte do representado (Rose, 2001). A fotografias do trapiche ou do terminal, no caso do Porto, da Capela, no caso da Capilha, e da linha da costa ocupada por banhistas, são sinédoques do todo representado por esses locais geográficos ou, ainda, partes do turismo/lazer local-regional, proporcionado pela Lagoa, e que ora são tomados como todo.

\section{CONSIDERAÇÕES FINAIS}

O turismo-atividade, possivelmente mais como o turismo-fenômeno, lida constantemente com a novidade, sempre fazendo surgir novos sítios, novas experiências e novas paisagens, ao mesmo tempo em que relega outros sítios, experiências e paisagens ao ostracismo, em escala regional, nacional ou global. Contudo, conforme este estudo pôde corroborar, as convenções estéticas que governam a percepção e o julgamento da paisagem, pelo menos da paisagem lacustre estudada, convivem com certa tradição, que remonta séculos passados. A estética romântica do pitoresco e, em menor medida, a do sublime, parecem-nos decisivas.

A sensibilidade estética é diversa para cada sujeito-turista que observa, vivencia e fotografa as paisagens lacustres em estudo. Contudo, isso também ocorre 
em nível de sociedade e de civilização, variando no tempo e no espaço, ou seja, essa sensibilidade possui historicidade e geograficidade. Em contraposição das experiências pré-fabricadas no turismo, as fotografias de paisagem estudadas parecem acenar para a unicidade da experiência turística de cada sujeito: o ideal seria tratar experiência(s) no plural. Dada certa obsessão por experiências na contemporaneidade, e sob o contexto de estetização do cotidiano, as questões apreciadas neste trabalho parecem centrais ao marketing e à comunicação turística.

As metodologias visuais se mostram relevantes nesse empreendimento, sobretudo se buscam incorporar a perspectiva dos sujeitos. Contudo, alertamos que essas metodologias ainda se encontram em grande parte calcadas no texto (escrito, mas não), o que pode e deve ser enfrentado. Além disso, a pesquisa qualitativa aqui empregada pode servir como etapa preliminar de uma pesquisa quantitativa, que vise à formulação e ao teste de hipóteses.

Futuramente, sugerimos como novas pesquisas: utilizar os comentários, comparar o material com as redes sociais e replicar a metodologia em outros sítios ou paisagens. Também, é recomendável acrescentar outros "textos", como o dos empreendedores, da comunidade residente, além dos gestores e pesquisadores muitos desses aparentemente autores das fotografias no Flickr, sendo necessário critérios para categorizá-los como tais. Quanto às práticas turísticas nas paisagens lacustres, especialmente em Lago Merín, é possível triangular os resultados deste com observações diretas, ou com entrevistas aos frequentadores. Além da triangulação metodológica, é relevante também a triangulação teórica entre distintas correntes de conceituação da paisagem - Fenomenologia, Nova Geografia Cultural, Semiótica, etc.

É possível utilizar os resultados desta pesquisa na gestão da "imagem" (ou do imaginário) do(s) destino(s), considerando as (des)continuidades em relação ao Brasil/Uruguai (gaps semióticos), tendo em conta que Lagoa é um único objeto, com distintas versões de suas paisagens turísticas. Além disso, a finalidade deste trabalho, ou os desdobramentos futuros, apontam para projetos e ações de interpretação das paisagens dos sítios estudados, a fim de dar-lhes visibilidades, ajudando a ressignificar os encontros dos sujeitos com essas paisagens lacustres (turistas ou não), e conferir identificações dos locais estudados com a Lagoa, locais esses até então não integrados pelo turismo regional transfronteiriço.

\section{REFERÊNCIAS}

Adler, J. (1989). Origins of sightseeing. Annals of Tourism Research, 16(1), p. 7-29.

Alecrim, E. (2018). Flickr muda de dono após 13 anos de Yahoo. Tecnoblog, 23 abr. 2018. Recuperado de <https://tecnoblog.net/240516/smugmug-compra-flickr/>, em 29 jul. 2019.

Agência de Desenvolvimento da Lagoa Mirim - ALM (2019). Bacia Hidrográfica da Lagoa Mirim. Recuperado de: <https://wp.ufpel.edu.br/alm/?page_id=2103>, em 01 ago. 2019.. Caderno Virtual de Turismo, 13(3), 91-105. 
Banks, M. (2009 Andriolo, A. (2016). A paisagem da cidade histórica e turística: fenomenologia da experiência estética). Dados visuais para pesquisa qualitativa. Porto Alegre: Artmed.

Bell, C. \& Lyall, J. (2008). The Accelerated Sublime: thrill-seeking adventure heroes in the commodified landscape. In Coleman, S. \& Crang, M. (Eds). Tourism: between place and performance (pp. 2134). New York/Oxford: Berghahn.

Bell, V. (2010). Visual methodologies and photographic practices: encounters with Hadrian's Wall World Heritage Site. In Burns, P., Lester, J. A. \& Bibbings, L. (Eds). Tourism and visual culture (pp.120-134). Oxfordshire: Cabi Publishing. 2 v.

Boyer, M. (2003). História do turismo de massa. Bauru: Edusc.

Brady, E.; Haapala, A. (2003). Melancholy as an aesthetic emotion. Contemporary Aesthetics, 1 (1), s. n.

Brook, I. (2014). Aesthetic appreciation of landscape. In Howard, P.; Thompson, I. \& Waterton, E. (Eds). The Routledge Companion to Landscape Studies (pp. 108-118). London: Routledge.

Cosgrove, D. (2002). Landscape and the European Sense of Sight - Eyeing the Nature. In Anderson, K. et al. (Eds). Handbook of Cultural Geography (pp. 249-268). London: Sage.

Crang, M. (2009). Visual methods and methodologies. In Delyser, D. et al. (Eds). The Sage Handbook of Qualitative Geography (p. 208-22). London: Sage Publishing.

Franklin, A. \& Crang, M. (2001). The trouble with tourism and travel theory? Tourist Studies, 1 (1), 5-22.

Flick, U. (2009). Introdução à pesquisa qualitativa. 3rd. ed. Porto Alegre: Artmed.

Flickr. Fotos. Recuperado de <https://www.flickr.com/>, em 29 jul. 2019.

Gastal, S. (2013). Imagem, Paisagem e Turismo: a construção do olhar romântico. Pasos, 11 (3), 123-133.

Hall, M. C. \& Valentin, A. (2005). Content analysis. In Ritchie, B. M., Burns, P. \& Palmer, C. (Eds). Tourism research methods: integrating theory with practice (pp. 191-210). Oxfordshire: CABI Publishing.

Hunter, W. C. (2016). The social construction of tourism online destination: a comparative analysis of the visual representation of Seoul. Tourism Management, 54(1), 221-229.

Jacobsen, J. K. S. (2007). Use of landscape perception methods in tourism studies: a review of photobased research approaches. Tourism Geographies, 9(3), 234-253.

Knudsen, D. C., Metro-Roland, M. M. \& Rickly-Boyd, J. M. (2014). Landscape studies and tourism research. In Howard, P.; Thompson, I. \& Waterton, E. (Eds). The Routledge Companion to Landscape Studies (pp. 269-285). London: Routledge.

Knudsen, D. C., Metro-Roland, M. M. \& Rickly-Boyd, J. M. (2015). Tourism, Aesthetics, and Touristic Judgment. Tourism Review International, 19(4), 179-191.

Knudsen, D. C., Rickly-Boyd, J. M. \& Metro-Roland, M. M. (2012). Landscape perspectives on tourism geographies. In Wilson, J. (Ed) The Routldege Companion to Tourism Geographies (pp. 201-207). London/New York: Routledge.

Larsen, J. (2006). Geographies of tourist photography: choreographies and performances. In Falkheimer, J. \& Jansson, A. (Eds). Geographies of Communication: the spatial turn in Media Studies (pp. 243261). Gottemburg: Nordicom. 
Tur., Visão e Ação, v22, n3, p508-532, Set./Dez. 2020 - Balneário Camboriú, Santa Catarina, Brasil

Löfgren, O. (1999). On holiday: a history of vacationing. Berkeley: University of California Press.

MacCannell, D. (1999). The Tourist: a new theory of the leisure class. Berkeley: University of California Press.

MacCannell, D. (2001). Tourist Agency. Tourist Studies, 1 (1), 23-27.

MacCannell, D. (2011). The ethics of sightseeing. Berkeley: University of California Press.

Meining, D. W. (1979). The beholding eye: ten versions of the same scene. In Meinig, D. W. (Ed). The interpretation of ordinary landscapes: geographical essays (pp. 33-50). New York/Oxford: Oxford University Press.

Minca, C. (2008). El sujeto, el paisaje y el juego posmoderno. In Nogué, J. (Ed). El paisaje en la cultura contemporánea (pp. 209-232). Madrid: Biblioteca Nueva.

Munar, A. M. \& Jacobsen, J. K. S. (2014). Motivations for sharing tourism experiences through social media. Tourism Management, 43(1), 46-54.

Nöth, W. (1995). Handbook of Semiotics. Bloomington/Indianapolis: Indiana University Press.

Picazo, P. \& Moreno-Gil, S. (2019). Analysis of the projected image of tourism destinations on photographs: a literature review to prepare for the future. Journal of Vacation Marketing, 25(1), 3-24.

Pimentel, M. R. (2010). Cataratas do Iguaçu: experiências e registros de uma paisagem (Dissertação de Mestrado em Geografia). Universidade Federal do Rio Grande do Sul. Porto Alegre.

Potocka, I. (2013). The Lakescape in the eyes of a tourist. Quaestiones Geographicae, 32(3), 85-97.

Rose, G. (2001). Visual methodologies: an introduction to the interpretation of visual materials. London: Sage Publications.

Santanella, L. \& Nöth, W. (2001). Imagem: cognição, semiótica, mídia. 3rd. ed. São Paulo: lluminuras.

Scarles, C. (2014). Tourism and the visual. In Lew, A. A., Hall, M. \& Williams, A. A. (Eds.). The Wiley Blackwell Companion to Tourism (pp. 325-335). West Sussex: Wiley Blackwell.

Schäfer, A. E., Lanzer, R. \& Pereira, R. (2009). Atlas socioambiental Lagoas Costeiras I. Caxias do Sul: Educs.

Soica, S. (2016). Tourism as practice of making meaning. Annals of Tourism Research, 61 (1), pp. 96-110.

Sontag, S. (2004). Sobre fotografia. São Paulo: Companhia das Letras.

Tresidder, R. (201 1). The Semiotics of Tourism. In Robins, P., Heitmann, S. \& Diecke, P. U. C. (Eds). Research Themes for Tourism (pp. 59-68). Oxfordshire: Cabi Publishing.

Tuan, Y.-F. (2012). Topofilia: um estudo da percepção, atitudes e valores do meio ambiente. Londrina: Eduel.

Urry, J. (1996). O olhar do turista: lazer e viagens nas sociedades contemporâneas. São Paulo: Nobel.

Urry, J. (1999). Sociology beyond societies. London: Routledge. 
VSÃO E AÇÃO

TURISMO E HOTELARIA DA UNIVERSIDADE DO VALE DO ITAJAI

Varnier, N. C. C. (2017). Ecoturismo e paisagem: a composição visual da paisagem como recurso para o ecoturismo no extremo sul do Brasil - RS. (Dissertação de Mestrado em Turismo e Hotelaria). Universidade do Vale do Itajaí. Balneário Camboriú.

Contribuição de cada autor na construção do artigo:

Jaciel Gustavo Kunz: Elaboração da estrutura teórica, coleta e análise de dados. Antonio Carlos Castrogiovanni: Orientação do trabalho e revisão crítica do conteúdo. 